\title{
Joint research projects will focus on social impact of Zika in Brazil
}

\section{Cláudia Collucci}

São Paulo

Researchers from the United Kingdom and Brazil are being invited to pitch projects that look at the social effects of the Zika virus in Brazil, in a partnership launched by the British Council and the Oswaldo Cruz Foundation (Fiocruz), whose aim is to promote health and social development through science and technology.

The programme will accept up to 10 projects to investigate capacity building to respond to or prevent social effects of congenital Zika syndrome in Brazil. Projects must involve Brazilian and British researchers and last between 18 and 24 months, and they will receive funding of up to $£ 100000$ ( $€ 115$ 000; \$130 000). The funds come from the Newton Fund (part of the UK's official development assistance), the British government, Fiocruz, and other Brazilian research institutions. The closing date for applications is 12 September.

At the launch of the initiative, Paulo Gadelha, president of Fiocruz, said that the partnership would help his foundation expand its operations. "This area often does not receive the priority it deserves. To emphasise the social aspects of Zika will remain a permanent challenge after the peak of the epidemic is passed. This partnership is very important and appropriate," he said.

Christopher Rodrigues, president of the British Council, emphasised three aspects of the partnership: that it highlights the social effects of new and neglected diseases; the attention it gives to the role of climate change on the human environment; and the establishment of research partnerships.

"They are partnerships between people and institutions and between countries. And as we know, by working together we are more likely to find answers than people working apart," he said.

To find out more go to https://www.britishcouncil.org/education/science/ current-opportunities/newton-institutional-links-july-2016?_ga=1. 178377124.105539404.1471878557.

Published by the BMJ Publishing Group Limited. For permission to use (where not already granted under a licence) please go to http://group.bmj.com/group/rights-licensing/ permissions 